\title{
Addendum of Sheikh Muhammad Baha-ud-Din Naqshband in the 'Principles of Naqshbandi Sufi Order' and its Effectiveness in accomplishing Psychological and Spiritual Advancement
}

\author{
M Zulqarnain \\ Department of Aqeedah \& Philosophy, Faculty of Usuluddin \\ International Islamic University Islamabad, Pakistan \\ Email: zulqarnain4386@gmail.com
}

\begin{abstract}
Naqshbandi Sufi Order gained distinguished fame around the globe due to its complete compatibility with Quran and Sunnah and abstain from invented heresies. One of the prominent Sufi Masters of Naqshband "Sheiek Abdul Khaliq al-Ghujdawani" introduced eight principles for spiritual enhancement. Shah Baha-ud-Din Naqshband added three more principles which were being recognized "Principles of Naqshbandi Sufi Order": Temporal pause (وقوف زمانى), Numerical pause (وقدى وقوف) (علبى), and Heart pause (وقدى). This research paper explored the effectiveness of these three principles in psychological and spiritual advancement. The systematic review of literature concluded that these principles played a significant role in psychological, ethical and spiritual enhancement. On one hand they made a strong link between man and Allah in terms of Tawheed, love, and unshakeable trust while on the other hand, provided an opportunity of self-purification from wrong emotions, desires and sinful inclination which ultimately led towards good morals as well as promotion of social peace. It is therefore suggested that religious scholars in general, and masters of Naqshbandi Sufi order should strictly advise their followers to follow these principles in order to get psychological and spiritual benefits. Qualitative and descriptive research approach was employed in this research for the analysis of data.
\end{abstract}

Keywords: Baha-ud-Din; Naqshban; Principle; Sufi Order; Spiritual Advancement

\section{INTRODUCTION}

There are many branches of Islamic science which are derived from the Quran and Sunnah. Some of the important disciplines of knowledge include Tafseer, Hadith, Fiqh, History, Seerah, Comparative Religions, and Ilm-e- Kalam. Sufism or Tasawuf is also an Islamic discipline which is an important segment of our social life [1]. It refers to a spiritual path on which one travels in order to purify his heart from sins, attain closeness to Allah Almighty, and become the Friend of Allah Almighty. In order to accomplish the objectives of Sufism, the disciple begins his journey by taking Bai'ah (البيعة) "Oath of Surrender" from one who has already travelled this path which is also known as Murshid, Pir, Sheikh, Sufi Master, Saint, and Sage. After taking the oath, there are many methods as to how the Sheikh will guide his disciple or 
Mureed to Allah. These different methods are known as Tariqahs or Sufi Orders out of which four orders are considered basic;

1. Naqshbandi Sufi Order (الطريقة النقشبندية)

2. Chisthi Sufi Order (الطريقة الجشتية)

3. Soharwardi Sufi Order (الطريقة السهروردية)

4. Qadri Sufi Order (الطريقة القادرية)

Though every order has its own methodology, practices, and regulations, however all of them lead toward Allah Almighty as the following diagram illustrates;

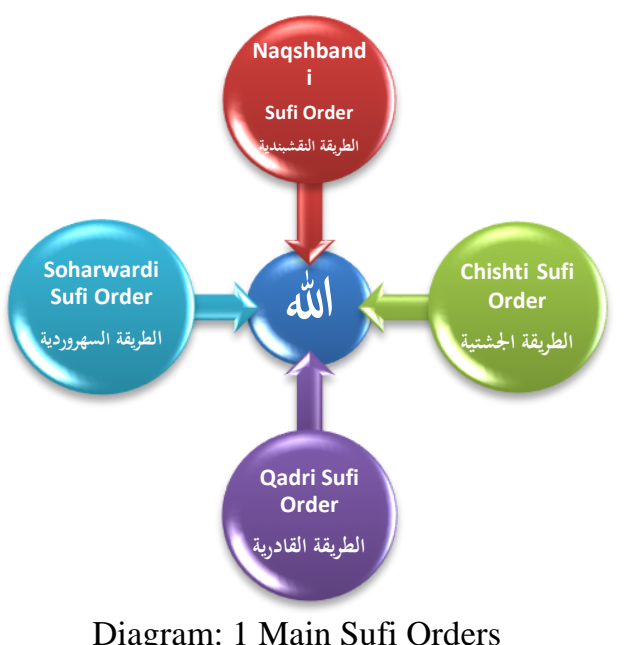

Historically, Sufi orders were formed in $12^{\text {th }}$ and $13^{\text {th }}$ centuries. In early stages, Sufism had been the prerogative of limited spiritual elite. From $12^{\text {th }}$ century onwards, it succeeded in involving the Muslim masses on a large scale in its network of orders. The master was supposed to teach his disciples (Murids) and perform rituals of Zikr and Hearing Sama [2]. Kabbani pointed out that there was an elaborate initiation ritual for the disciple when he was admitted into full membership (usually after three years). In this ceremony he received from the Sheikh a special cloak (Khirqa) which symbolized his devotion to God [3].

Each Sufi order developed its own particular method of Zikr to attain spiritual advancement. The Sufism thus appeared as an influential force into the society which attracted the attention of all social classes towards Zikr and Sama. Sufis played an unbelievable role in the spiritual and moral development of people which Fuqahah (Jurists) could not do. They also established the hospices to travelers, traders and merchants on different routes. Their code of conduct, morality and soft heartedness attracted the people as Rahman revealed that most of the Muslims belonged to some Sufi Order between $13^{\text {th }}$ and $18^{\text {th }}$ century [4].

\section{A. Principles of Naqshbandi Sufi Order}

The word Naqshbandi is interpreted as engraver (of heart). This way of Sufism is also known as "the sublime Sufi path" or "the way of the golden chain". It was established in $13^{\text {th }}$ Century in Central Asia on account of defending Islam against ravages of the Mongol invasions. Later on, it widely spread in Indian subcontinent. According to Kabbani, Naqshbandiya was basically developed as an urban order whose followers used to recite Zikr silently. Unlike other orders, music, dance and Sama were strictly prohibited in this order [5].

There are two basic principles of Sufism: "tawhid" (Nothing exists except Allah) and "tawakkul" (absolute trust in Allah). "Tawhid" refers to the interpretation that nothing truly exists except Allah. The God's love to man and Man's love to God is also a central theme of Islamic Sufism. In addition to these two basic principles (tawakkul \& tawhid), one of the greatest Sufi Masters of the Naqshbandi Sufi Order 'Abdul Khaliq al Ghujdawani' established eight (08) systematic principles [6] for spiritual development which are being considered "Principles of Naqshbandi Sufi Order" and also known as "Naqshbandi expressions or Naqshbandi terms or 
Naqshbandi codes". Naqshbandi Sufi order is based upon these expressions. He named the following phrases for these principles shown in the diagram; [7]

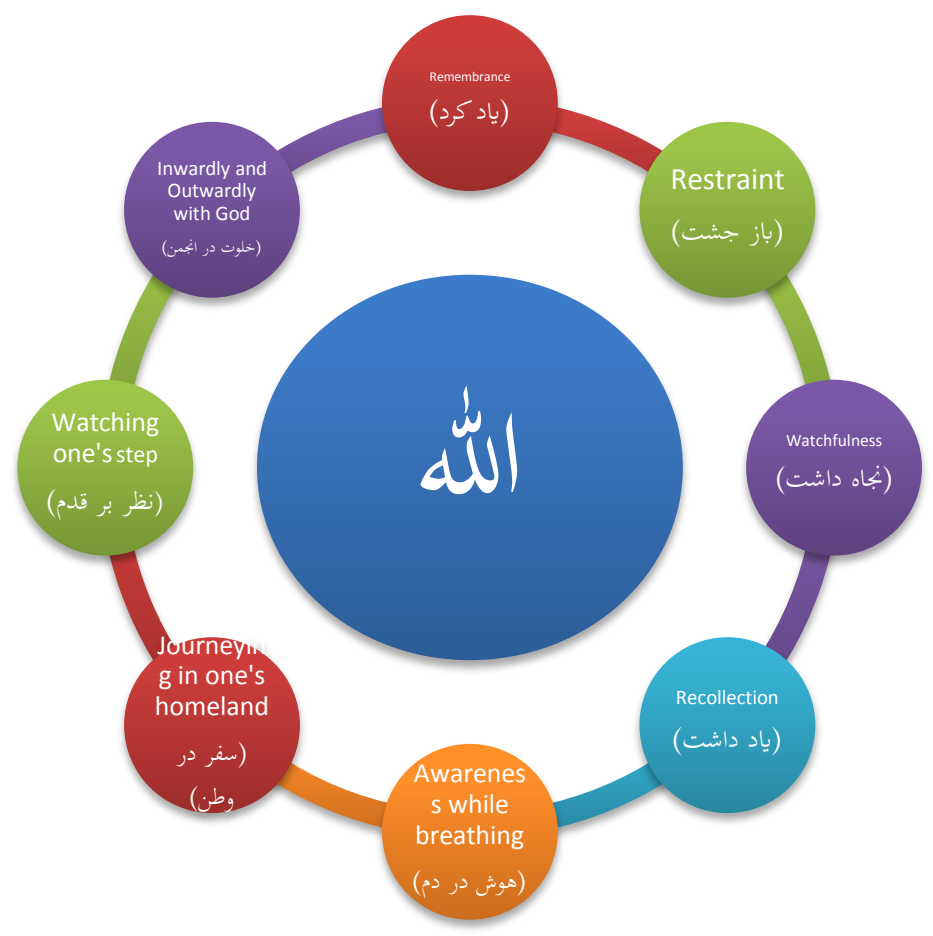

Diagram: 2 Principles of Naqshbandi Sufi Order

1. Remembrance (Yad kard): Always orally and mentally repeating the dhikr.

2. Restraint (Baz gasht): Engaging in the heart repetition of the phrase "Al-kalimat at-tayyiba".

3. Watchfulness (Nigah dasht): Being conscientious over wandering thoughts while repeating the phrase "Al-kalimat attayyiba.

4. Recollection (Yad dasht): Concentration upon the Divine presence in a condition of dhawq.foretaste rintuitive anticipation or perceptiveness 'not using external aids

5. Awareness while breathing (Hosh dar dam): Controlling one's breathing by not exhaling or inhaling in the forgetfulness of the Divine.

6. Journeying in one's homeland (Safar dar watan): An internal journey that moves the person from having blameworthy to praiseworthy properties. This is also referred to as the vision or revelation of the hidden side of the shahada.

7. Watching one's step (Nazar bar qadam): Do not be distracted from purpose of the ultimate journey 'Solitude in a crowd (Khalwat dar anjuman).

8. Although journey is outwardly in this world it is inwardly with God

B. Addendum of Shah Baha-ud-Din in the Principles of Naqshbandi Sufi Order

Shah Baha-ud-Din Naqshband (13181389 A.H) was one of the most revered and distinguished Sufis of Bukhara, Uzbekistan. He was the founder of the largest Sufi Muslim order, the 'Naqshbandi' [8]. He was spiritually trained by Baba Muhammad Sammasi and had a strong relationship with Sammasi's principal khalifa (successor), Amir Kulal. According to some Sufis, he also received training from gyaib (unseen) from Abdul Khaliq Gujdawani [9].

The status of Shah Baha-ud-Din Naqshband could be assessed by the contribution that "al-Tariqah alNaqshbandiah” (الطريقة النقشبندية) is attributed to him. One of his unique spiritual works was the addition of three (03) principles in this Sufi Order [10]. This addition made this order more effective and left immense influence on the psychological, ethical and spiritual development. Presently, these eleven principles are considered as the base or foundation of Naqshbandi school order. We try to explain these three principles and their effectiveness in psychological and spiritual enhancement.

The visual presentation of these three principles is given below in a diagram. 


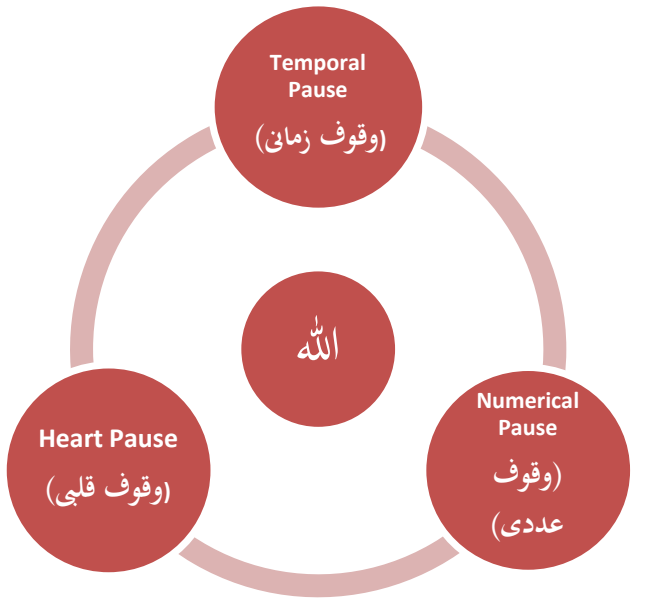

Diagram: 3 Addition of Three Principles

\section{1- Temporal pause (وقوف زمان)}

It refers to keep into account the way one spends his time. If time is spent rightfully one should be thankful to Allah and if time is spent incorrectly one should ask for forgiveness. There are two dimensions of temporal pause: Self recognition (واقف نفس) and Recognition of Self condition (واقف حال). Self-recognition refers to take care one's self by getting engage all the times in Pas Anfas (ياس انفاس) so that he should inhale every breath with the remembrance of Allah. Recognition of Self condition (واقف حال) refers to take care of time as if disciple spends his time in obedience, must be thankful to Allah and in case of spending time in disobedience must ask forgiveness. In mysticism, this exercise is called “Accountability” (محاسبة).

Allah Almighty has explained this state in Noble Quran:

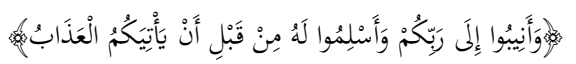

"And return to your Lord and submit to Him before the punishment comes upon you" [11].

\section{2- Numerical pause (وقوف عددى)}

Numerical pause refers to checking that the "heart-zikr" has been repeated the requisite number of time taking into account one's wandering thoughts. According to Tahir Raza Bukhari, it refers to becoming aware of the digit in the Zikr that the disciple must finish the Zikr on odd number, not on even [12].

It seems that this principle is derived from the tradition of Holy Prophet as he gave particular importance to odd number in different aspects of life. Our beloved Prophet Muhammad PUBH revealed the important of odd number in worships:

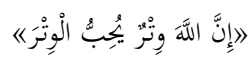

"Allah is odd and likes odd numbers" [13].

\section{3- Heart pause (وقوف قلى)}

Forming a mental picture of one's heart with the name of God engraved to emphasize that the heart has no consciousness or goal other than God. In this principle the heart only focuses upon Allah and tries to engrave the mental picture of Allah in the heart by continuous remembrance and repetition of his name. This concept is derived from the Noble Quran as Allah Almighty has ordained to remember him all the times (from morning to evening). The Holy Quran emphasized on the remembrance of Allah in Surah Al-Ahzab;

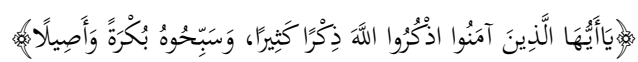

"O you who have believed, remember Allah with much remembrance, And exalt Him morning and afternoon" [14].

Likewise Allah Almighty has appreciated those believers who do not become thriftless during the trade and financial transaction.

$$
\text { مانَ }
$$

"The men whom neither commerce nor sale distracts from the remembrance of Allah..." [15].

Once a servant asked the Sheikh Baha-udDin about Leisure (فراغت). He replied that the 
heart should not incline towards love of world. It doesn't mean that one should leave his material needs or responsibilities but the love of world is prohibited.

\section{Effectiveness of Above-Mentioned Principles in Psychological and Spiritual Advancement}

The main objective of Naqshbandi Sufi Order is to get the nearness and recognition of Allah. For this purpose, eleven principles (11) are formed by Naqshbandi Sufis. These principles play a significant role in psychological and spiritual development which purify heart from sins and guide towards right actions. Some of the effects of these principles are listed below;

\section{Psychological Effects}

These principles leave numerous positive effects on human mind. Some of them are listed below;

* Refine thought from ambiguities, provide awareness of purposeful life, enhance level of concentration, restrain from laziness, encourage to take part actively in worldly affairs by paying attentions simultaneously towards Allah, develop good morals, and promote peace into the society.

* Play an important role in getting rid of fear, despair, anxiety, worldly stress, depression and other complex mental disorders.

* Boost the capabilities of mental faculties, increase potential power and prepare man for maximum production by the sense of responsibility and accountability.

* Enhance self-confident, skills, expertise, talent, and level of competency which induce an individual to achieve life goals with enthusiasm.
* Make man brave, courageous, focused, ambitious and targeted oriented in life and refrain him from illegal, unethical, immoral, impermissible and unbeneficial activities.

* Bring feeling of security, satisfaction, happiness, pleasure and contentment in life.

* Provide an opportunity of living pure, healthy, satisfied, and beneficial life with no regrets.

\section{Spiritual Effects}

There are uncountable effects of these principles in spiritual development. Some of them are listed below;

* Soften heart and develop the behavior of forgiveness, pardon, kindness, sympathy mercy, and softness.

* Abstain heart from evil inclinations, thoughts, wishes, desires, emotions and attitudes and encourage to perform righteous actions with ease, passion and vigour.

* Instigate to take care of inner \& outer purification by removing the stains of spirit and enlighten the heart with faith and zikr.

* Increase the power of spirit and strengthens the insight so one can see the unseen. One of the unique examples is the address of second rightly guided caliph Hazrat Umar who advised during his sermon of Friday prayer to Hazrat Saria to be careful of enemies in war.

* Kindle the fire of Allah's love in the heart, increase the warmth level, provide awareness and nearness of Allah which ultimately make man recognized friend of Allah.

* Lead towards the attainment of Qalb-eSaleem (قلب سليم) which is meant by "Peaceful Heart". 
* Lead towards success in this life and hereafter as Holy Quran named this life “Hayat-e-Tayyiba" (الحياة الطيبة).

* Make life colorful comprised of peace, dignity, respect, satisfaction, happiness and tranquility.

* Enable man to receive love, blessings, abundance, and prosperity from Allah Almighty.

\section{METHOD}

The main objective of this academic work was to explore the effectiveness of Addendum of Hazrat Muhammad Baha-ud-Din Naqshband in the 'Principles of Naqshbandi Sufi Order'. Qualitative and descriptive research approach was employed for the collection and analysis of data. The author consulted the documents related to biographies of Shah-e-Naqshbandi. Previously published and parallel literature including books, research articles, periodicals, theses, were pulled in to produce sound, systematic and authentic research, as well as to measure the effects on psychological and spiritual enhancement. In addition to that, secondary sources including Internet and library were used after careful assurance of their validity and reliability. The data was divided into three sections as mentioned in abstract.

\section{RESULTS AND DISCUSSION}

The main purpose of this research was to explore the effectiveness of principles of Naqshbandi Sufi order in psychological and spiritual advancement. The review of literature concluded that Naqshband Sufi Order was based on eleven principles. First eight principles were formed by Sheikh Abdul Khaliq Gujdawani, while other three principles were added by Shah Bahauddin Naqshband. These principles left positive impact on both: psychological and spiritual level.

\section{CONCLUSIONS \& RECOMMENDATIONS}

. In Psychological context, these principles refined human thought, enhanced level of concentration, restrained from laziness; increased self-confident, developed skills, expertise and talent, enhanced level of competency and encouraged to take part actively in worldly affairs, developed good morals, promoted peace into the society. Moreover, they boosted the capabilities of mental faculties, increased potential power and prepared man for maximum production and made him courageous, focused, ambitious and target oriented in life, refrained him from illegal, unethical, immoral, impermissible and unbeneficial activities. They became a source of removing doubts, getting rid of fear, despair, anxiety, worldly stress, depression and other complex mental disorders. They also blew the feelings of security, satisfaction, happiness, pleasure and contentment and provided an opportunity of living pure, healthy, satisfied, and beneficial life with no regrets. In spiritual context, these principles developed the behavior of forgiveness, pardon, kindness, sympathy mercy, and softness by abstaining heart from bad inclinations, thoughts, wishes, desires, emotions and attitudes and encouraged to perform righteous actions with ease, passion and vigour. They instigated to take care of inner \& outer purification by removing the stains of spirit and enlighten the heart with faith and zikr. The result of following these principles appeared in the form of an increase in power of spirit and strength of insight. The heart was kindled with the love of Allah which increased the level of submission and bestowed the nearness of Allah which ultimately made man a recognized friend of 
Allah. They made life full of peace, satisfaction, happiness and tranquility by the love, blessings, abundance, and prosperity from Allah Almighty. The Ultimate result of these principles could be summed up in one verse of Holy Quran;

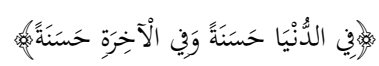

"Good in this world and good and in the Hereafter" [16].

\section{REFERENCES}

[1] Kamal Akhtar. Socio-political life in India during 16th-17th centuries as reflected in the Sufi literature. $\mathrm{PhD}$ diss., India, Aligarh Muslim University, 2008, 1.

[2] Amal M. A. Ibrahim \& Yousif Omer Babiker, The Principles of Naqshbandi Sufi Order, Mujallah tul Uloom al-Insaniyyah. Vol. 14 (2), 2013, 2.

[3] Kabbani, M.H. The Naqshbandi Sufi Way, (History and Guidebook of the Saints of the Golden Chain). USA, Kazi Publications, 1995, 2 .

[4] Rahman, S. A. A Dictionary of Muslim Names, New Delhi, Good word Books, 2001.

[5] Kabbani, M.H. Classical Islam and the Naqshbandi Sufi Tradition, USA, Islamic Supreme Council of America, 2001.

[6] Necdet Tousm, Baha-ud-Din Naqshband (A Central Asia Sufi), Translated by Jane Louise Kandur, Istanbul, Insan Publication, 2008, 62.
In the light of above cited literature it is recommended that the religious scholars should give awareness to Muslims about principles of Naqshbandi Sufi order. On one hand, these principles will enhance psychological and spiritual advancement while on the other hand, they will promote peace and prosperity in the society.

[7] Amal M. A. Ibrahim \& Yousif Omer Babiker, The Principles of Naqshbandi Sufi Order, Mujallah tul Uloom al-Insaniyyah, Vol. 14 (2), 2013, 2.

[8] Hadarah Rajab, Tareqah Naqsyabandiyah and its impact on character refinement in south Sulaewsi, JICSA, Vol. 1 (2), 2012, 2.

[9] Schubel, Vernon James. Naqshbandis in Western and central Asia, change \& continuity, Istanbul, Swedish Research Institute, 1997, 78.

[10] Bukhari, Tahir Raza. Naqshbandi Sulook-oTasawuf, Jihat-ul-Islam, Vol. 7 (1), 2013, 97.

[11] Surah Al-Zumar, 39:54.

[12] Bukhari, Tahir Raza. Naqshbandi Sulook-oTasawuf, Jihat-ul-Islam, Vol. 7 (1), 2013, 98.

[13] Suleman, Abu Daud. Sunan Abi Daud, Bairut, Dar-ul-Kitab al-Arabi, Hadith no. 1418. Status of Hadith: Authentic, 533.

[14] Surah Al-Ahzab: 33:41-42.

[15] Surah Al-Noor, 24: 37.

[16] Surah Al-Baqarah, 2: 201. 